\title{
Forage cactus (Opuntia ficus-indica Mill) meal in rabbit diets in the growth phase
}

Farelo de palma forrageira (Opuntia ficus-indica Mill) na dieta de coelhos em fase de crescimento

Animal Nutrition Received on: 23/10/2019 Accepted on: 19/06/2020

PASCOAL. Leonardo Augusto Fonseca ${ }^{1 *}$ 0000-0002-7225-5251

SILVA, Kivia Alessandra Gouveia da ${ }^{2}$ 0000-0002-8506-514X

WATANABE, Pedro Henrique ${ }^{3}$ 0000-0002-1010-2305

BRITO, José Mares Felix ${ }^{2}$ 0000-0001-9461-3016

SILVA, Jordanio Fernandes $\mathrm{da}^{2}$ 0000-0003-1540-5986

\begin{abstract}
DANTAS JUNIOR, Paulo Rodrigues ${ }^{2}$ 0000-0002-2041-4441
\end{abstract}

SILVA, David Rwbystanne Pereira da ${ }^{2}$ 0000-0002-9804-0355

BRITO, Mariany de Souza ${ }^{4}$ 0000-0003-4942-3576

BEZERRA, Ana Patricia Almeida ${ }^{2}$ 0000-0002-8779-0337

ALMEIDA, Jonathan Mádson dos Santos ${ }^{2}$ 0000-0003-1729-6680

${ }^{1}$ Universidade Federal da Paraíba - Ciência Animal Centro de Ciências Humanas, Sociais e Agrárias, Campus III , Joao Pessoa 58051-900, Brazil

${ }^{2}$ Universidade Federal da Paraíba - Ciência Animal Cidade Universitária, Campus III, Bananeiras, PB 58220-000, Brazil

${ }^{3}$ Universidade Federal do Ceará - Zootecnia Av. Mister Hull 2977 , Fortaleza, CE 60020-181, Brazil

${ }^{4}$ Universidade Federal Rural de Pernambuco - Zootecnia Av. Gregório Ferraz Nogueira, Serra Talhada, Pernambuco 56909-535, Brazil

*Corresponding author: leonardo@cchsa.ufpb.br

\section{ABSTRACT}

Two experimental tests were carried out to evaluate the inclusion of forage cactus meal in diets for rabbits during the growth phase. In the first test 14 male New Zealand red rabbits were used, housed in metal cages, and distributed in a completely randomly design with two treatments and seven replicates with one animal per experimental unit. The digestibility of the nutrients and the digestible energy of the forage cactus meal were determined by the total feces collection method. The forage cactus meal presented $92.24 \%$ of DM, $5.63 \%$ of CP and $2,347 \mathrm{kcal}$ of DE/ $\mathrm{kg}$. In the second test the inclusion of $0,10,20$ and $30 \%$ forage cactus meal in the rabbit diet was tested for productive performance, carcass characteristics, viscera and economic viability. Thus, 40 male rabbits of the New Zealand red breed were used, distributed in metal cages, completely random designed with four treatments, five replicates and two animals per experimental unit. No influence of inclusion levels $(\mathrm{P}>0.05)$ on performance variables, housing 
characteristics or economic viability was observed. The forage cactus meal can be included in up to $30 \%$ in the diets of growing rabbits.

KEYWORDS: Alternative feedstuff, cactaceous, metabolism, nutrition, soluble fiber.

\section{RESUMO}

Foram realizados dois ensaios experimentais para avaliar a inclusão do farelo de palma forrageira em dietas para coelhos durante a fase de crescimento. No primeiro ensaio foram utilizados 14 coelhos machos Nova Zelândia vermelha, alojados em gaiolas metálicas, e distribuídos em delineamento inteiramente ao acaso, com dois tratamentos e sete repetições com um animal por unidade experimental. Foram determinadas a digestibilidade dos nutrientes e a energia digestível do farelo de palma pelo método da coleta total de fezes. O farelo de palma forrageira apresentou 92,24\% de MS, 5,63\% de $\mathrm{PB}$ e $2.347 \mathrm{kcal}$ de ED/kg. No segundo ensaio foi testada a inclusão de 0, 10, 20 e 30\% de farelo de palma forrageira na dieta de coelhos e avaliado o desempenho produtivo, as características de carcaça, vísceras e a viabilidade econômica. Para tanto, foram utilizados 40 coelhos machos da raça Nova Zelândia vermelha, distribuídos em gaiolas metálicas, em delineamento inteiramente ao acaso, com quatro tratamentos, cinco repetições e dois animais por unidade experimental. Não se observou influência $(\mathrm{P}>0,05)$ da inclusão em níveis do farelo de palma sobre o desempenho produtivo, as características de carcaça e a viabilidade econômica. O farelo de palma pode ser incluído em até de $30 \%$ na dieta de coelhos em crescimento.

PALAVRAS CHAVE: alimentos alternativos, cactácea, fibra solúvel, metabolismo, nutrição.

\section{INTRODUCTION}

Rabbits in the growing phase represent $60 \%$ of the herd on a wedge farm. Thus, there is a need to use more expensive ingredients such as cereals such as soybean meal and corn due to the nutritional and energy demand of the animals in this phase. However, due to the physiological need for dietary fiber by rabbits, there is the possibility of including ingredients with high fiber content from grasses and/or legumes in the rabbit feed.

Corn is still the main energy ingredient used in animal feed, and its price may vary depending on the time of year or region of the country, therefore requiring a search for alternatives which partially or totally replace it. Thus, the forage cactus (Opuntia ficus-indica Mill), which is commonly supplied in feeding ruminant animals, presents itself as a possible ingredient for feeding rabbits.

The forage cactus is a plant adapted to the climatic conditions of the semiarid region due to its morphophysiological characteristics (Neto et al., 2013). It is a species which has a remarkable energy level regarding its nutritional composition, with an average content of approximately $62 \%$ of non-fibrous carbohydrates and total digestible nutrients (Wanderley et al., 2002; Melo et al., 2003). On the other hand, it contains levels considered low for neutral detergent fiber (26\%), dry matter $(12 \%)$ and crude protein (4.7\%) 
(Cavalcanti, 2013). However, with a view to its use in rabbits' feeds, there is a need to dehydrate the forage cactus due to the high water content by generally using the sun drying process with subsequent grinding to obtain the cactus meal. Considering its composition in total carbohydrates and mainly due to the high content of non-fibrous carbohydrates, forage cactus meal in rabbit food can also favor the hindgut fermentation process due to the lower flow of undigested starch to the large intestine.

Studies with fresh forage cactus or in the form of meal for rabbits are scarce. In evaluating possible alternatives for feeding rabbits in the growth phase such as a mixture containing ramie and forage cactus and observing the nutritional needs of rabbits, Ferreira et al. (2009) concluded that the mixture can be used in $25 \%$ in the diet of rabbits.

The objective of this study was to evaluate the nutritional value of forage cactus meal and the use of its nutrients and energy, as well as the effects of including it in the diet of rabbits in the growth phase on productive performance, carcass characteristics and economic evaluation.

\section{MATERIAL AND METHODS}

Two experimental tests to evaluate the nutrition characteristics and determine the inclusion levels of forage cactus meal in the diet of growing rabbits were carried out at the Cuniculture Laboratory belonging to the Department of Animal Science of the Center for Human, Social and Agrarian Sciences (CCHSA-UFPB). The nutritional and energetic composition, the digestibility coefficients and the energy of palm bran were evaluated in the first trial. Next, the productive performance, carcass characteristics, relative viscera weight and economic evaluation were evaluated in the second test based on the forage cactus meal inclusion levels for growing rabbits. The experimental protocols were approved by the Ethics Committee for the Use of Animals (CEUA) of the Federal University of Paraíba (No. 012/2016).

The forage cactus was purchased from producers in the municipality of Casserengue-PB located about $30 \mathrm{~km}$ from the CCHSA. The Opuntia ficusindica Mill (giant forage cactus) variety was chosen because of its greater availability in the region.

The cladodes from the cacti were initially collected in the field, sliced into pieces of 3 to $5 \mathrm{~cm}$ and exposed to the open air for a maximum of five days to dehydrate. During the night, the material was covered with plastic canvas to prevent it from acquiring moisture. The pieces were crushed in a conventional crusher in a later stage, and the forage cactus meal was obtained.

\section{Experiment 1}

A total of 14 New Zealand Red rabbits, 32 days old and with an initial weight of $649.5 \pm 17.6 \mathrm{~g}$ were used to determine the digestibility coefficients and the nutritional and energetic value of forage cactus meal. The animals were distributed in a completely randomized design with two treatments, seven replications and one animal per experimental unit. The animals were housed in metal cages with nylon screens to facilitate the feces collection and allow the flow of urine.

The treatments consisted of a reference diet (Table 1), and another test showing $70 \%$ of the reference diet and $30 \%$ forage cactus meal. The reference feed 
was formulated to meet the nutritional needs for growing rabbits according to the recommendations of Lebas et al.
(1999). The diets were subsequently mixed and pelleted.

Table 1. Percent composition and Nutritional values of the reference diet for growing rabbits.

\begin{tabular}{lc}
\hline Ingredients $^{1}$ & Reference diet (\%) \\
\hline Corn bran & 30.000 \\
Soybean meal & 25.512 \\
Wheat bran & 20.000 \\
Sugarcane bagasse & 17.273 \\
Soybean oil & 2.000 \\
DL - methionine & 0.009 \\
Inert & 1.972 \\
Calcitic limestone & 1.118 \\
Dicalcium phosphate & 1.024 \\
Sodium chloride & 0.672 \\
Mineral and vitaminic supplement ${ }^{2}$ & 0.400 \\
BHT ${ }^{3}$ & 0.020 \\
\hline Total & 100.00 \\
\hline Calculated values & \\
\hline Digestible energy (kcal/kg) & 2900.00 \\
Crude protein $(\%)$ & 17.455 \\
Lysine $(\%)$ & 0.9192 \\
Methionine + total cystine $(\%)$ & 0.5500 \\
Starch $(\%)$ & 26.940 \\
Crude fiber (\%) & 14.000 \\
Neutral detergent fiber $(\%)$ & 31.340 \\
Acid detergente fiber $(\%)$ & 16.470 \\
Calcium $(\%)$ & 0.8000 \\
Total phosphorus $(\%)$ & 0.6000 \\
\hline
\end{tabular}

${ }^{1}$ Values proposed by Lebas et al. 1999. ${ }^{2}$ Mineral and vitaminic supplement: Vit A, 600.000 UI; Vit D, 100.000 UI; Vit E, 8000 mg; Vit K3, 200 mg; Vit B1, 400 mg; Vit B2, 600 mg; Vit B6, 200 mg; Vit B12, 2000 mcg; Pantothenic acid, 2000 mg; Hill, 70.000 mg; Fe, 8000 mg; Cu, 1200 mg; Co, 200 mg; Mn, 8600 mg; Zn, 12.000 mg; I, 64 mg; Se, 16 $\mathrm{mg}$; Antioxidant $20.000 \mathrm{mg}$. ${ }^{3}$ Butyl hydroxytoluene.

The experimental period was 12 days with seven days for adaptation of the animals to the facilities and diets, and five days for the feces collection using the total collection method.

Stool collections were carried out twice a day, once in the morning and once in the afternoon, and then individually packed in plastic bags and stored at $18^{\circ} \mathrm{C}$. The feces from each experimental unit were homogenized at the end of the collection period. The material was weighed and placed in a forced ventilation oven at $55^{\circ} \mathrm{C}$ for 72 hours. In the next stage, the material was weighed and ground and samples of the dry material were taken to the laboratory for analysis.

The forage cactus meal, ration and fecal samples were analyzed to determine the dry matter (DM), crude protein (CP), mineral matter $(\mathrm{MM})$, organic matter 
$(\mathrm{OM})$, crude fiber $(\mathrm{CF})$, detergent fiber neutral (NDF) and acid detergent fiber (ADF) values according to the AOAC (2005). The gross energy (GE) of the forage cactus meal, feed and feces was measured in a Parr model 6100 calorimetric pump.

Next, the digestibility coefficients of $\mathrm{DM}, \mathrm{OM}, \mathrm{MM}, \mathrm{CP}, \mathrm{CF}, \mathrm{NDF}, \mathrm{ADF}$ and GE were calculated based on the results of laboratory analyzes of the rations, feces and forage cactus meal, as well as the digestible energy and the respective digestible nutrients of the forage cactus meal diet using the equations proposed by Matterson et al. (1965).

\section{Experiment II}

In order to evaluate the inclusion of different levels of forage cactus meal $(0$,
10, 20 and 30\%), 40 male New Zealand red rabbits, 32 days old and average weight of $706.6 \mathrm{~g} \pm 1.65 \mathrm{~g}$ were used. The animals were distributed in a completely randomized design with four treatments and five replications and two animals per experimental unit. The animals were housed in galvanized wire cages containing a feeder and drinker.

The percentage composition and nutritional values of the forage cactus meal were obtained in the digestibility test to formulate the experimental diets for the second test (Table 2). The diets were formulated in order to meet the nutritional requirements according to the nutritional recommendations for growing rabbits proposed by Lebas (1999).

Table 2. Percent composition and Nutritional values of experimental diets for growing rabbits.

\begin{tabular}{|c|c|c|c|c|}
\hline \multirow{2}{*}{ Ingredients } & \multicolumn{4}{|c|}{ Experimental diets } \\
\hline & $0 \% \mathrm{FC}^{1}$ & $10 \% \mathrm{FC}$ & $20 \% \mathrm{FC}$ & $30 \% \mathrm{FC}$ \\
\hline Corn bran & 28.00 & 22.20 & 16.11 & 11.80 \\
\hline Soybean meal & 22.53 & 22.86 & 23.50 & 24.75 \\
\hline Forage cactus meal & 0.00 & 10.00 & 20.00 & 30.00 \\
\hline Palm bead & 17.50 & 17.00 & 16.40 & 14.00 \\
\hline Tifton hay & 18.12 & 17.60 & 15.55 & 11.60 \\
\hline Sugarcane bagasse & 5.20 & 3.17 & 1.91 & 1.77 \\
\hline Soybean oil & 2.81 & 2.70 & 2.70 & 2.47 \\
\hline Dicalcium phosphate & 2.22 & 2.24 & 2.26 & 2.26 \\
\hline Calcitic limestone & 1.00 & 0.00 & 0.00 & 0.00 \\
\hline Sodium chloride & 0.66 & 0.66 & 0.67 & 0.67 \\
\hline DL - methionine & 0.06 & 0.06 & 0.08 & 0.10 \\
\hline L-threonine & 0.02 & 0.04 & 0.05 & 0.05 \\
\hline Mineral and vitaminic supplement ${ }^{2}$ & 0.40 & 0.40 & 0.40 & 0.40 \\
\hline $\mathrm{BHT}^{3}$ & 0.02 & 0.02 & 0.02 & 0.02 \\
\hline Inert & 1.47 & 1.05 & 0.35 & 0.11 \\
\hline Total & 100.00 & 100.00 & 100.00 & 100.00 \\
\hline \multicolumn{5}{|l|}{ Calculated values } \\
\hline Digestible energy (kcal/kg) & 2600.29 & 2603.30 & 2600.13 & 2600.23 \\
\hline Crude protein $(\%)$ & 17.00 & 17.00 & 17.00 & 17.00 \\
\hline Lysine $(\%)$ & 0.82 & 0.83 & 0.83 & 0.85 \\
\hline
\end{tabular}




$\begin{array}{lcccc}\text { Methionine (\%) } & 0.30 & 0.30 & 0.32 & 0.34 \\ \text { Threonine (\%) } & 0.60 & 0.60 & 0.60 & 0.60 \\ \text { Tryptophan (\%) } & 0.20 & 0.20 & 0.20 & 0.20 \\ \text { Starch (\%) } & 24.76 & 22.04 & 19.13 & 16.89 \\ \text { Crude fiber (\%) } & 12.00 & 13.18 & 13.92 & 14.66 \\ \text { Neutral detergent fiber (\%) } & 17.85 & 33.30 & 32.68 & 31.09 \\ \text { Acid detergente fiber (\%) } & 8.00 & 17.28 & 17.51 & 17.49 \\ \text { Calcium (\%) } & 1.10 & 1.10 & 1.49 & 1.86 \\ \text { Total phosphorus (\%) } & 0.80 & 0.79 & 0.79 & 0.77\end{array}$

${ }^{1} \mathrm{FC}$ - Forage cactus meal;. ${ }^{2}$ Mineral and vitaminic supplement: Vit A, $600.000 \mathrm{UI}$; Vit D, 100.000 UI; Vit E, $8000 \mathrm{mg}$; Vit K3, $200 \mathrm{mg}$; Vit B1, $400 \mathrm{mg}$; Vit B2, $600 \mathrm{mg}$; Vit B6, $200 \mathrm{mg}$; Vit B12, $2000 \mathrm{mcg}$; Pantothenic acid, $2000 \mathrm{mg}$; Hill, 70.000 mg; Fe, 8000 mg; Cu, 1200 mg; Co, 200 mg; Mn, 8600 mg; Zn, 12.000 mg; I, 64 mg; Se, 16 mg; Antioxidant $20.000 \mathrm{mg} .{ }^{3}$ Butyl hydroxytoluene.

The diets were dry pelleted and the animals were provided with them ad libitum. The productive performance of the animals was monitored from 32 days to 67 days of age. The animals and the rations were weighed to determine the following performance variables: feed consumption, weight gain and feed conversion.

The animals were submitted to 12 hours of fasting at the end of the experimental period (at 67 days of age), being weighed again to obtain the slaughter weight that served as a reference for calculating the relative carcass weight. The slaughtering was performed by cervical dislocation followed by bleeding and evisceration. The carcass was obtained and weighed shortly after the head and feet were removed. The relative weights of the viscera, liver and internal fat were determined after slaughter. The carcasses were cooled for 24 hours at a temperature of 1 to $2^{\circ} \mathrm{C}$ so that they could subsequently be subjected to quantitative evaluation according to the American NPPC method (1991).

Carcass yield (CY) was obtained using the formula: $[\mathrm{CY} \%=($ Carcass weight $*$ 100)/Body weight]; and the cold (CCW) and hot (HCW) carcass weights. The cold (CCY) and hot (HCY) carcass yields were calculated using the following formulas: $(\mathrm{HCY}=$ HCW/ALW $\mathrm{x}$ 100) and (CCY = CCW/ALW x 100), with the animal's live weight (ALW) being considered.

The prices of the ingredients described in Table 3 were used to check the economic feasibility of including different forage cactus meal levels in the diet of growing rabbits. These were the prices of the ingredients in the Northeast Region throughout the experimental period. 
Table 3 - Avarege price of ingredients used in experimental diets

\begin{tabular}{lclc}
\hline Ingredients & $\mathbf{R \$ / k g}$ & \multicolumn{1}{c}{ Ingredients } & $\mathbf{R \$ / k g}$ \\
\hline Corn grain $8.8 \%$ & 0.73 & Dicalcium phosphate & 4.00 \\
Soybean meal, 45\% & 1.78 & Calcitic limestone & 0.38 \\
Soybean oil & 3.78 & DL-Methionine & 11.00 \\
Palm bran & 0.60 & L-Threonine & 14.28 \\
Wheat bran & 0.89 & Sodium chloride & 0.34 \\
Tifton hay & 1.29 & BHT & 18.09 \\
Sugarcane bagasse & 0.28 & & \\
\hline
\end{tabular}

Some ingredients had price quoted in dollars (\$) and converted to reais (R\$), being subject to Exchange rate fluctuations. Grain costs are appreciably subject to price changes. The mineral and vitamin supplements that integrate the diets in the proportion of $0.4 \%$ do not interference in this case in the comparasion of the economic viabiity indexes.

The following indices were determined for the economic viability calculations of experimental diets:
The average feed cost per kilogram of live weight (Yi) during the experimental period was calculated using the equation described by Bellaver et al. (1985):

In which:

$$
Y i=\frac{Q i x P i}{G i}
$$

$\mathrm{Yi}=$ Average feed cost per kilogram gained in the $\mathrm{i}^{\text {th }}{ }^{\text {treatment; }}$

$\mathrm{Pi}=$ Average price per kilogram of the feed used in the $\mathrm{i}^{\text {th }}{ }^{\text {theatment; }}$ trent;

Qi $=$ Quantity per kilogram of the feed used in the $i_{-}{ }^{\text {th }}$ treatment;

$\mathrm{Gi}=$ average weight gain of the $\mathrm{i}^{\text {th }}$ treatment.

The economic efficiency index (EEI) and the average cost index (CI) were calculated using the adapted model by Barbosa et al. (1992):

In which:

$$
\mathrm{IEE}=\frac{\text { MCe }}{\text { Ctei }} \times 100 \quad \mathrm{e} \quad \mathrm{IC}=\frac{\text { Ctei }}{\text { MCe }} \times 100
$$

Mce $=$ Lowest Yi between treatments;

$\mathrm{CTei}=\mathrm{Yi}$ in the treatment considered.

The data obtained were analyzed using the Cramer Van-Misses test at 5\% submitted to analysis of variance using the SAS statistical program (SAS version 9.1) and multiple linear regressions were performed up to the third degree. The treatment means were compared with the control treatment $(0 \%$ FC) by the Dunnet test at $5 \%$.

\section{RESULTS AND DISCUSSION}

\section{Experiment I}

The nutritional composition values obtained for the forage cactus meal indicate that it has high fiber content, even so it presented high digestibility coefficients of dry and organic matter ( 92.48 and $91.92 \%$, respectively), which can be related to forage cactus presenting a high content of soluble fibers and possibly due to the high fermentability of these compounds (Table 4). 
Table 4. Composition, digestibility coefficients, nutrients and digestible energy of forage cactus meal for growing rabbits (Natural Matter)

\begin{tabular}{lccc}
\hline Nutrients and energy & Composition & $\begin{array}{c}\text { Digestibility } \\
\text { Coefficients }\end{array}$ & $\begin{array}{c}\text { Digestible nutrients } \\
\text { and Energy }\end{array}$ \\
\hline Dry matter (\%) & 92.24 & 92.48 & 85.30 \\
Organic matter (\%) & 86.35 & 91.92 & 79.37 \\
Mineral matter(\%) & 13.65 & 49.54 & 6.76 \\
Crude protein (\%) & 5.63 & 56.44 & 3.18 \\
Crude fiber (\%) & 19.66 & 51.83 & 10.19 \\
Neutral detergent fiber (\%) & 69.35 & 63.24 & 43.85 \\
Acid detergent fiber (\%) & 20.67 & 51.18 & 10.57 \\
Gross energy (kcal/kg) & 3511.47 & 66.86 & 2347.77 \\
\hline
\end{tabular}

The values found in relation to the low crude protein content $(5.63 \%)$ are within the results obtained by Menezes et al. (2007) $(5.30 \%)$ and those found by Lira et al. (2006) (5.00\%). Cacti have low levels of crude protein in their constitution, and require strategies for nutritional enrichment even with its adaptive characteristics, especially regarding crude protein levels (Araújo et al., 2008).

In this context, Syomiti et al. (2014) evaluated the chemical composition of the forage cactus in different parts of the plant according to the cladode maturity stage, finding that nutritional values vary according to the part and degree of maturity, thus indicating that nutritional value varies according to maturity. The study in question used forage cactus meal, and it was prepared with different parts of the plant without considering the degree of maturity of the plant, which may have contributed to the high levels of CF, NDF and ADF.

There was also a reduced digestible protein content $(3.18 \%)$ of the ingredient for rabbits, with this effect being possibly due to the interaction of the fiber on the protein. The protein results in less nutrient availability when it is complexed to insoluble fiber, in addition to hindering its degradation in the animal's digestive tract. Soluble fibers also impair the digestibility of proteins because they increase the viscosity of the intestinal contents, reducing the action of proteolytic enzymes. In addition, they play a role as a substrate for microbial fermentation at the cecal level and contribute to endogenous nitrogen losses (Jansmann, 2002).

Digestibility coefficients of $51.83 \%$, $63.24 \%$ and $51.18 \%$ were respectively observed regarding the digestibility of fibrous fractions (crude fiber, neutral detergent fiber and acid detergent fiber) contained in forage cactus meal, possibly due to the presence of cellulose and lignin since these compounds are used in lower quantities by rabbits. However, it was observed that the digestibility coefficient of the fiber in acid detergent found was higher than that reported in the literature of $25.77 \%$ by Tosto et al. (2007).

Regarding digestible energy, the forage cactus meal presented 2,347.77 kcal of $\mathrm{DE} / \mathrm{kg}$, being lower than that of corn (3260 kcal of DE $/ \mathrm{kg}$ ) and close to that of wheat bran $(2190 \mathrm{kcal}$ of DE $/ \mathrm{kg})$.

In evaluating the chemical composition of forage cactus in the diet of rabbits, Ferreira et al. (2009) found similar dry 
matter $(90.93 \%)$, organic matter $(84.28 \%)$ and acid detergent fiber (18.75\%) values to those obtained in the present study, with only the crude protein $(3.63 \%)$ and neutral detergent fiber $(29.59 \%)$ values differing. Factors such as species, age of the plant and time of year can modify the chemical composition of the forage cactus (Santos, 2006), in addition to the type of soil in the region and the variety of the forage cactus.

\section{Experiment II}

There was no effect $(\mathrm{P}>0.05)$ of the inclusion of forage cactus meal at the levels of $0 \%, 10 \%, 20 \%$ and $30 \%$ on the following productive performance variables: average daily feed consumption, average daily weight gain, feed conversion and final weight in diets for rabbits in the growing phase (Table $5)$.

Table 5. Levels of inclusion of forage cactus meal in diets for growing rabbits on average daily feed consumption (ADFC), average daily weight gain (ADWG), feed conversion (FC) and final weight (FW)

\begin{tabular}{lllll}
\hline Variables & Levels of inclusion of forage cactus meal & $\mathrm{VC}^{1}(\%)$ & Regressio & $\mathrm{P}$
\end{tabular}

$\mathrm{n}$

\begin{tabular}{lccccccc} 
& \multicolumn{1}{c}{$0 \%$} & $10 \%$ & $20 \%$ & $30 \%$ & & & \\
\hline ADFC(g) & 101.81 & 103.64 & 105.25 & 107.07 & 16.28 & $\mathrm{NS}^{2}$ & 0.9658 \\
ADWG & 35.51 & 35.36 & 35.91 & 32.81 & 19.17 & NS & 0.8787 \\
(g) & & & & & & & \\
FC & 2.86 & 2.96 & 2.95 & 3.27 & 7.37 & NS & 0.0771 \\
FW(g) & 2034.5 & 1886.0 & 2003.2 & 1840.2 & 14.68 & NS & 0.6363 \\
\hline
\end{tabular}

${ }^{1}$ VC- Variation coefficients, the means did not show significant differences when compared by the de Dunnet test $(\mathrm{P}>0,05) .{ }^{2} \mathrm{NS}-$ Non significant $(\mathrm{P}>0.05)$.

The absence of influence of including the forage cactus meal on the productive performance variables suggests that the nutritional quality of the diets were maintained as the inclusion level of forage cactus meal increased, suggesting good acceptance of the ingredient in the diets by the animals.

Unlike what was observed in this study, Zabut et al. (2007) evaluated the consumption of forage cactus cladodes for rabbits, reducing the supply of pelleted feed by 20, 40 and $60 \%$, respectively, and verified worsening in the animals' performance as it was offered the forage cactus cladode in natura; the difference in the results found by the authors when compared to this study being that we used forage cactus meal and tried to formulate the diets so that they met the nutritional requirements so that the animals were able to maintain performance parameters.

Diets for non-ruminants present satisfactory amounts of non-starch polysaccharides in their composition which increase the viscosity of the intestinal contents with damage to the digestive and absorptive processes (Retore et al., 2010). However, the inclusion of up to $30 \%$ of forage cactus meal for growing rabbits did not compromise the digestion and absorption processes of nutrients.

Similar results were observed by Arruda et al. (2003) in testing different sources of fiber (alfalfa hay or soy husk), and did 
not find any influence on the performance variables of growing rabbits.

In a study evaluating the performance of New Zealand White rabbits fed with alfalfa hay and manioc branch hay, the authors observed that animals which received the reference diet showed greater weight gain and better feed conversion from 35 to 50 days (Faria et al., 2008).

There was no effect $(\mathrm{P}>0.05)$ of the inclusion of different levels of forage cactus meal in the diet of rabbits for the hot carcass weight $(\mathrm{HCW})$, cold carcass weight $(\mathrm{CCW})$, carcass yield (CY), viscera weight (VIW) and liver weight (LIVW) variables (Table 6).

Table 6. Levels of inclusion of forage cactus meal in diets for growing rabbits on hot carcass weight $(\mathrm{HCW})$, cold carcass weight $(\mathrm{CCW})$, carcass yield $(\mathrm{CY})$, viscera weight (VW) and liver weight (LW)

\begin{tabular}{|c|c|c|c|c|c|c|c|}
\hline \multirow[t]{2}{*}{ Variables } & \multicolumn{4}{|c|}{$\begin{array}{l}\text { Levels of inclusion of forage cactus } \\
\text { meal }\end{array}$} & \multirow[t]{2}{*}{$\begin{array}{c}\mathrm{VC}^{1}(\% \\
)\end{array}$} & \multirow[t]{2}{*}{$\begin{array}{c}\text { Regressio } \\
\mathrm{n}\end{array}$} & \multirow[t]{2}{*}{$\mathrm{P}$} \\
\hline & $0 \%$ & $10 \%$ & $20 \%$ & $30 \%$ & & & \\
\hline $\mathrm{HCW}(\mathrm{g})$ & 1146.7 & 1047.7 & 1108.6 & 1006.5 & 17.63 & $\mathrm{NS}^{2}$ & 0,5857 \\
\hline $\operatorname{CCW}(\mathrm{g})$ & 1116.8 & 1026.7 & 1081.7 & 960.5 & 16.45 & NS & 0,4453 \\
\hline CY(\%) & 56.15 & 55.25 & 55.31 & 54.20 & 5.09 & NS & 0,6203 \\
\hline VW(g) & 363.58 & 349.94 & 374.76 & 375.74 & 18.85 & NS & 0,9163 \\
\hline LW(g) & 58.38 & 51.26 & 57.60 & 48.56 & 25.71 & NS & 0,5850 \\
\hline
\end{tabular}

${ }^{1}$ VC- Variation coefficients, the means did not show significant differences when compared by the de Dunnet test $(\mathrm{P}>0,05) .{ }^{2} \mathrm{NS}-$ Non significant $(\mathrm{P}>0.05)$.

In supplying forage cactus cladodes in natura and ad libitum to reduce the supply of pelleted feed, Zabut et al. (2007) found changes in organ weights and carcass weight. The authors justify this influence due to the metabolic process of ingesting forage cactus in natura.

Similarly, no influence of fiber sources on carcass yield was found in a study in which different fiber sources (alfalfa hay or soybean husks) were tested for growing rabbits (Arruda et al., 2003).

Corroborating these results, it was observed that the substitution of $50 \%$ and $100 \%$ of the alfalfa hay with the soybean husk had no effect on the carcass yield or the liver weight of rabbits in the growing phase (Toledo et al., 2012).

The nutritional role of including fiber from the forage cactus meal in the rabbits' diet probably consisted of the fermentation process, the selective retention of particles in the cecum-colon and cecotrophagy. Such processes provide greater digestive efficiency of the fiber, use of volatile fatty acids, essential amino acids, water-soluble vitamins and certain electrolytes or minerals given the physiological processes of these animals (Arruda et al., 2003).

Economic indices were not influenced $(\mathrm{P}>0.05)$ by including different levels of forage cactus meal in the diets of growing rabbits (Table 7). Although forage cactus meal has a lower kilogram value than corn (which was the ingredient with the greatest proportional substitution), no statistical differences were observed. 
Table 7. Levels of inclusion of forage cactus meal in diets for growing rabbits on the cost of the diet, cost of the diet per $\mathrm{Kg}$ of weight gained (Yi), cost index (CI) and economic efficiency index (EEI)

\begin{tabular}{lcccccc}
\hline \multirow{2}{*}{ Economic indices } & \multicolumn{3}{c}{ Levels of inclusion of forage cactus meal } & \multirow{2}{*}{ VC, \% } & $\mathrm{P}$ \\
\cline { 2 - 5 } & $0 \%$ & $10 \%$ & $20 \%$ & $30 \%$ & & \\
\hline Feed cost & 1.05 & 1.03 & 1.02 & 0.98 & & \\
Yi $(\mathrm{R} \$ / \mathrm{kg})$ & 2.98 & 3.37 & 3.03 & 3.67 & 9.52 & 0.322 \\
$\mathrm{CI}(\%)$ & 100.0 & 113.4 & 101.7 & 123.2 & 9.52 & 0.322 \\
EEI $(\%)$ & 100.6 & 91.41 & 100.0 & 83.10 & 16.03 & 0.262 \\
\hline
\end{tabular}

${ }^{1}$ VC- Variation coefficients, the means did not show significant differences when compared by the de Dunnet test $(\mathrm{P}>0,05)$.

\section{CONCLUSION}

Forage cactus meal has $2,347.77 \mathrm{kcal} / \mathrm{kg}$ of digestible energy and nutritional contents which make it an ingredient that can be used, and may be included in up to $30 \%$ proportion in diets for growing rabbits.

\section{REFERENCES}

ARRUDA, A.M.V.; PEREIRA, E.S.; MIZUBUTI, I.Y.et al. Importância da fibra na nutrição de coelhos. Semina: Ciências agrárias, Londrina, v.24, n.1, p.181-190, 2003.

ARAUJO, L.F. et al . Enriquecimento proteico da palma forrageira com Saccharomyces cerevisiae para alimentação de ruminantes. Arquivo Brasileiro de Medicina Veterinária e Zootecnia, Belo Horizonte, v. 60, n. 2, p. 401-407, 2008 .

Association of Official Analytical Chemists (AOAC). Official methods of analysis, volume 2,18 th edition. AOAC, Maryland, USA. 2005.

BARBOSA, H. P. et al. Triguilho para suínos nas fases inicial de crescimento, crescimento e terminação. Revista da Sociedade Brasileira de Zootecnia. v.21, n.5, p.827-837, 1992.

CAVALCANTE, LAD; SANTOS, GRA; SILVA, LM; FAGUNDES, JL, \& SILVA, MA. Respostas de genótipos de palma forrageira a diferentes densidades de cultivo. Revista Pesquisa Agropecuária Tropical, vol. 44, no. 4, pp. 424-433. 2014.

FARIA, H.G; FERREIRA, W. M; SCAPINELLO, C; \& OLIVEIRA, C.E.A. Efeito da utilização de dietas simplificadas, à base de forragem, sobre a digestibilidade e o desempenho de coelhos Nova Zelândia. Revista Brasileira de Zootecnia, 37(10), 17971801.2008.

FERREIRA， R.C.; SILVA， R.A.; VIANA, E.P.T. et al. Alimentação alternativa para coelhos à base de rami (Boehmeria nivea) e palma (Opuntia ficus). Revista Verde (Mossoró - RN Brasil) v.4, n.3, p. $61-69,2009$.

JANSMANN, A.J.M. Evaluation trough literature data of the amount and amino acid composition of basal endogenous 
crude protein at the terminal ileum of pigs.Animal Feed Science and Technology, v. 98, n.1-2, p.49-60, 2002.

LEBAS, F. Recomendações alimentares: alimentação dos coelhos. In: INRA Alimentação dos animais monogástricos: suínos, coelhos e aves. 2.ed. São Paulo: Roca, 1999. p.76-84.

LIRA, M.A.; SANTOS, M.V.F.; CUNHA, M.V.; MELLO, A.C.L.; FARIAS, I.; SANTOS, D.C. A Palma Forrageira na Pecuária do Semiárido. In: GOMIDE, C.A.M. et al. Alternativas Alimentares para Ruminantes. Aracaju: Embrapa Tabuleiros Costeiros, 2006. cap.1, p. 17-33.

LOWE, J. A. Pet Rabbit Feeding and Nutrition. In: DE BLAS J. C.; WISEMAN J. The nutrition of the rabbit. 2 ed. Cambridge: CAB International, 2010. p. 294-313.

MACHADO, L.C.; FERREIRA, W.M.; BORGES, I. et al. Avaliação das Dietas Simplificadas e Semi-simplificadas, com base na mistura de forrageiras, com e sem enzimas, para coelhos em crescimento. Ciência Animal Brasileira, Goiânia, v.13, n.3, p. 330337, 2012.

MATTERSON, L.D.; POTTER, L.M.; STUTZ, M.W. et al.The metabolizable energy of feed ingredients for chickens. Research Report, v.7, p.11-14, 1965.

MELO, A. A. S. de; FERREIRA, M. de A.; VÉRAS, A. S. C.; LIRA, M. de A.; LIMA, L. E. de; VILELA, M. da S.; MELO, E. O. S. de; ARAÚJO, P. R. B. Substituição parcial do farelo de soja por ureia e palma forrageira (Opuntia ficus indica Mill) em dietas para vacas em lactação. I. Desempenho. Revista Brasileira de Zootecnia, v.32, n.3, p.727-736, 2003.

MENEZES, D.R.; ARAÚJO, G.G.L.; SOCORRO, E.P.; OLIVEIRA, R.L.; BAGALDO, A.R; SILVA, T.M. Efeito da inclusão de níveis crescentes de ureia sobre o consumo e digestibilidade em dietas contendo resíduo desidratado de uva e palma forrageira para ovinos. Ciência Rural, Santa Maria, 2007.

NATIONAL PORK PRODUCERS COUNCIL - NPPC. Procedures to evaluate market hogs. 3rd ed. Des Moines: NPPC, 1991. 16p.

NETO, JP; SOARES, PC; BATISTA, AMV; ANDRADE, SFJ; ANDRADE, RPX; LUCENA, RB, \& GUIM, A 2016, 'Balanço hídrico e excreção renal de metabólitos em ovinos alimentados com palma forrageira (Nopalea cochenillifera Salm Dyck). Revista Pesquisa Veterinária Brasileira, vol. 36 , no. 4, pp. 322-328.

RETORE, M., SILVA, L.P., TOLEDO, G.S.P., \& ARAÚJO, I.G. Efeito da fibra de coprodutos agroindustriais e sua avaliação nutricional para coelhos. Arquivo Brasileiro de Medicina Veterinária e Zootecnia, 62(5), 1232-1240. 2010.

SANTOS，R.M.M.G.; COSTA，R.G.; SILVA, J.H.V. Efeito da substituição da proteína do farelo de soja pela proteína do feno de amoreira (Morus alba) na dieta de coelhos em crescimento. Revista Agropecuária Técnica, v.27, n. 1, p.49-52, 2006.

SYOMITI M., MARANGA E.K, OBWOYERE G.O, GEBRU G AND 
DANA H. Chemical Composition of Cactus ( Opuntia ficus-indica) and Prosopis Species (Prosopis juliflora) as Drought-resilient Feed Resources in Kenya. Journal of Environment Natural Resources Management and Society. v. p. 41-47, 2014.

TOSTO, M.S.L.; ARAÚJO, G.G.L.; OLIVEIRA, R.L. et al. Composição química e estimativa de energia da palma forrageira e do resíduo desidratado de vitivinícolas. Revista Brasileira de Saúde e Produção Animal, v.8, n.3, p. 239-249, 2007.

TOLEDO, G.S.P; EGGERS, D.P; SILVA, L.P; PACHECO, P.S; KLINGER, A.C.K; CAPITÂNIO, J.R; SCHMIDT, T; ORTIZ, J. Casca de soja em substituição ao feno de alfafa em dietas fareladas para coelhos em crescimento. Ciência Rural, vol. 42, núm. 10, pp. 1896-1900. 2012.

WANDERLEY, W. L.; FERREIRA, M. de A.; ANDRADE, D. K. B. de; VÉRAS, A. S. C.; LIMA, L. E. de; DIAS, A. M. de A. Palma forrageira (Opuntia ficus indica Mill) em substituição à silagem de sorgo (Sorghum bicolor (L.) Moench) na alimentação de vacas leiteiras. Revista Brasileira de Zootecnia, v.31, n.1, p.273-281, 2002.

ZABUT, B. M; ALQEDRA, I. A; ABUSHAMMALAH, K. N. Evaluation of cactus cladodes as a partial feed for growing rabbits in the Gaza Strip. Livestock Research for Rural Development. $V .19,155, \mathbf{2 0 0 7}$ 